ISSN : $2302-1590$

E-ISSN: $2460-190 \mathrm{X}$

\title{
ECONOMICA
}

Journal of Economic and Economic Education Vol.2 No.2 (116 - 125)

\section{PENGARUH JUMLAH ANGGOTA DANSIMPANAN ANGGOTA TERHADAP PENINGKATANSISA HASIL USAHA (SHU) PADA PKP-RI (PUSAT KOPERASI PEGAWAI REPUBLIK INDONESIA) PROPINSI SUMATERA BARAT}

\author{
Ferline Ariesta \\ Mahasiswa Program Studi Pendidikan Ekonomi STKIP- PGRI Sumbar \\ J1. Gunung Pangilun No.1, Padang Sumatera Barat \\ Email: fer-line@yahoo.com \\ Yolamalinda \\ Dosen Program Studi Pendidikan Ekonomi STKIP- PGRI Sumbar \\ Jl. Gunung Pangilun No.1, Padang Sumatera Barat \\ Email: yolamalinda@gmail.com \\ Submited: 2014.02.29 Reviewed:2014.03.09 Accepted: 2014.04.12 \\ http://dx.doi.org/10.22202/economica.2014.v2.i2.224
}

\begin{abstract}
PKP-RI West Sumatra province has been doing some commercial businesses in order to gain the maximum profit or SHU, including the savings and loan and unit sales of the business is expected to contribute greatly to the achievement of the objectives of the cooperative. The purpose of this study is 1) to determine the factors that affect the balance of the (SHU) PKP-RI province of West Sumatra, 2) to examine and analyze the effect of the number of members and the amount of deposits to the balance of the acquisition (SHU) at PKP-RI West Sumatra province, and 3) to test and analyze the variables that have a significant effect between the number of members and the amount of savings to the acquisition of the balance of the PKP-RI in West Sumatra province.The research has pointed out that 1) the factors that affect the rest of the results of operations in the PKP-RI West Sumatra province, namely the number of members and member savings, 2) the number of members, member savings and influential sales together to increase PFM - RI SHU Province West Sumatra, and 3) between the number of members, member savings and sales that have a significant influence on the increase in PKP-RI SHU West Sumatra is a members' savings, which is obtained t of 4.548.
\end{abstract}

\section{Abstrak}

PKP-RI Propinsi Sumatera Barat selama ini telah melakukan beberapa usaha komersil dalam rangka mendapatkan laba atau SHU yang maksimal, diantaranya adalah unit simpan pinjam dan penjualan, dari usaha tersebut diharapkan dapat memberikan kontribusi yang besar terhadap pencapaian tujuan koperasi. Tujuan penelitian ini yaitu 1) untuk mengetahui faktor-faktor yang mempengaruhi Sisa Hasil Usaha (SHU) PKP-RI Propinsi Sumatera Barat, 2) untuk menguji dan menganalisis pengaruh jumlah anggota dan jumlah simpanan terhadap perolehan Sisa Hasil Usaha (SHU) pada PKP-RI Propinsi Sumatera Barat dan 3) untuk menguji dan menganalisis variabel yang mempunyai pengaruh signifikan antara jumlah anggota dan jumlah simpanan terhadap perolehan. Hasil penelitian menunjukkan bahwa 1) faktor-faktor yang mempengaruhi sisa hasil usaha pada PKP-RI Propinsi Sumatera Barat yaitu jumlah anggota dan simpanan anggota, 2) jumlah anggota, simpanan anggota, dan penjualan berpengaruh secara bersama-sama terhadap peningkatan SHU PKP-RI Propinsi Sumatera Barat, dan 3) diantara jumlah anggota, simpanan anggota, dan penjualan yang mempunyai pengaruh signifikan terhadap peningkatan SHU PKP-RI Propinsi Sumatera Barat adalah simpanan anggota, yaitu diperoleh $t_{\text {hitung }}$ sebesar 4,548.

Keywords : Number of Members, Member Savings, Member Participation, Sales, and Business Profits 


\section{PENDAHULUAN}

Pembangunan Nasional yang dilakukan oleh bangsa Indonesia adalah pembangunan manusia seutuhnya yang bertujuan untuk mewujudkan masyarakat yang adil dan makmur yang berdasarkan pancasila dan Undang-Undang Dasar 1945 (UUD 1945).Pemerintah secara tegas menetapkan bahwa dalam rangka pembangunan nasional dewasa ini, koperasi harus menjadi tulang punggung dan wadah bagi perekonomian rakyat. Kebijaksanaan Pemerintah tersebut sesuai dengan isi UUD 1945 pasal 33 ayat 1 yang menyatakan bahwa perekonomian disusun sebagai usaha bersama berdasarkan asas kekeluargaan.

Di dalam penjelasan UUD 1945 tersebut diungkapkan bahwa bangun usaha yang sesuai adalah koperasi.Oleh karena itu, peran koperasi menjadi penting berkaitan dengan pelaksanaan tujuan di atas.Koperasi harus tampil sebagai organisasi yang dapat mengumpulkan dan membentuk kekuatan ekonomi bersamasama agar dapat meningkatkan kesejahteraan anggota pada khususnya dan masyarakat pada umumnya.Oleh sebab itu tidak heran kalau koperasi sering kali diistilahkan sebagai sokoguru perekonomian yang bermakna sebagai pilar atau penyangga utama perekonomian.

Dewasa ini koperasi tumbuh dan berkembang diseluruh pelosok Indoneia, bergerak dibidang usaha menurut jenisnya masing-masing. Sejalan dengan kesadaran masyarakat akan pentingnya arti koperasi bagi masyarakat terutamamasyarakat kecil yang bertumbuh secara bersama perkembangan ilmu teknologi dan perekonomian bangsa Indonesia, tetapi tidak semua masyarakat Indonesia bernasib baik untuk dapat mengikuti perkembangan tersebut dan dikoperasilah mereka masyarakat kecil bergantung berusaha memenuhi kebutuhan hidupnya.

Menurut Undang-Undang No. 17 Tahun 2012 tentang perkoperasian dijelaskan bahwa koperasi adalah badan hukum yang didirikan oleh orang perseorangan atau badan hukum koperasi, dengan pemisahan kekayaan para anggotanya sebagai modal untuk menjalankan usaha, yang memenuhi aspirasi dan kebutuhan bersama di bidang ekonomi, social, dan budaya sesuai dengan nilai dan prinsip koperasi. Sedangkan menurut SAK (2007: 7), koperasi adalah badan usaha yang mengorganisir pemanfaatan dan pendayagunaan sumber daya ekonomi para anggota atas dasar prinsip-prinsip koperasi dan kaidah ekonomi untuk meningkatkan taraf hidup anggota pada khususnya dan masyarakat daerah pada umumnya.

Besar kecilnya modal yang ada pada koperasi akan berpengaruh terhadap aktivitas koperasi itu sendiri, dengan demikian faktor modal dalam koperasi ini merupakan salah satu alat yang ikut menentukan maju mundurnya koperasi. Tanpa adanya modal, sesuatu usaha yang bersifat ekonomis tidak akan dapat berjalan sebagaimana mestinya.

Demi kelancaran dan keberhasilan segala macam usaha yang dijalankan oleh koperasi tentu tidak lepas dari adanya kesadaran, kemampuan, berpartisipasi serta peran aktif anggota dan masyarakat sekitarnya. Tentu dengan catatan dukungan modal yang memadai untuk mengembangkan usaha tersebut serta peran dan kemampuan pengurus dalam melaksanakan, mengelola, dan menjalankan berbagai kebijakan demi menarik minat konsumen untuk mau menggunakan jasa yang ditawarkan dan masuk menjadi anggota koperasi.

PKP-RI merupakan unit usaha yang bergerak dibidang perdagangan barang, pelayanan jasa simpan pinjam yang mana penjualannya dilakukan secara tunai maupun kredit.PKP-RI menjual produk kepada anggota dan kelompok secara tunai maupun kredit.

$$
\text { Dalam sebuah koperasi, }
$$
keanggotaannya memiliki karakteristik yang membedakannya dengan badan usaha lain. Anggota koperasi memiliki identitas ganda, yaitu sebagai pemilik dan pengguna 
jasa koperasi (Ikatan Akuntan Indonesia; PSAK No.27).

Sebagai pemilik, anggota dapat berpartisipasi menginvestasikan dananya, partisipasi anggota dalam menginvestasikan dana tersebut disampaikan dalam bidang keuangan yang dinyatakan dengan pemenuhan kewajiban pembayaran simpanan. Aturan penentuan simpanan bervariasi, karena simpanan ditetapkan sesuai dengan kemampuan anggota, dan jauh dari unsur paksaan.

Sebagai pelanggan, anggota dapat berpartisipasi dengan melakukan aktivitas keuangan lainnya yaitu mendapatkan pinjaman. Hal ini berdasarkan pasal 89 Undang-Undang Nomor 17 Tahun 2012 tentang perkoperasian dan penjelasannya yang telah diatur bahwa koperasi dapat menghimpun dana dan mengeluarkannya melalui usaha simpan pinjam. Dengan keaktifan partisipasi para anggota dalam berkoperasi maka kegiatan koperasi dapat berjalan dengan lancar. Semakin banyak transaksi-transaksi pada koperasi oleh anggota maupun bukan anggota akan semakin meningkatkan Sisa Hasil Usaha koperasi.

Keaktifan anggota berpartisipasi dapat berupa aktif dalam transaksi kegiatan usaha dan juga dalam pembiayaan koperasi berupa simpanan pokok, simpanan wajib, simpanan sukarela serta pemanfaatan berbagai potensi usaha pelayanan yang disediakan koperasi akan meningkatkan modal koperasi, terutama modal kerja dam omset usaha koperasi. Hal ini tentu akan membuat koperasi berkembang menjadi lebih baik dan akan menguntungkan anggota terutama dengan adanya kenaikan perolehan sisa hasil usaha koperasi, Ditinjau dari laporan Sisa Hasil Usaha (SHU) yang diperoleh Koperasi PKP-RI Propinsi Sumatera Barat selama tigabelas tahun terjadi fluktuasi seperti terlihat pada tabel 1

Tabel 1.Perkembangan Sisa Hasil Usaha (SHU) PKP-RIPropinsi Sumatera Barat 20002012

\begin{tabular}{cccccccc}
\hline Tahun & $\begin{array}{c}\text { Jumlah } \\
\text { Anggota } \\
(\text { Orang) }\end{array}$ & $\begin{array}{c}\text { Simpanan } \\
\text { Anggota } \\
(\mathrm{Rp})\end{array}$ & $\begin{array}{c}\text { Partisipasi } \\
\text { Anggota } \\
(\mathrm{Rp})\end{array}$ & $\begin{array}{c}\text { Penjualan } \\
(\mathrm{Rp})\end{array}$ & $\begin{array}{c}\text { SHU } \\
(\mathrm{Rp})\end{array}$ & $\begin{array}{c}\text { Perubahan } \\
\text { SHU } \\
(\mathrm{Rp})\end{array}$ & $\begin{array}{c}\text { Perubahan } \\
\text { SHU } \\
(\%)\end{array}$ \\
\hline 2000 & 95.325 & 2.304 .016 .082 & 754.902 .811 & 484.158 .930 & 386.665 .934 & - & - \\
2001 & 92.058 & 2.141 .257 .292 & 912.392 .388 & 220.540 .573 & 387.957 .201 & 1.291 .267 & $0,33 \%$ \\
2002 & 90.790 & 2.527 .887 .944 & 975.254 .971 & 330.001 .677 & 519.518 .383 & 131.561 .182 & $25,32 \%$ \\
2003 & 87.370 & 2.868 .112 .252 & 813.546 .565 & 370.278 .943 & 215.324 .601 & $(304.193 .782)$ & $(141,27 \%)$ \\
2004 & 87.265 & 3.307 .340 .295 & 867.042 .472 & 290.231 .875 & 238.959 .736 & 23.635 .135 & $9,89 \%$ \\
2005 & 86.649 & 4.092 .500 .301 & 940.553 .169 & 229.841 .573 & 246.485 .952 & 7.526 .216 & $3,05 \%$ \\
2006 & 86.333 & 4.967 .830 .148 & 1.081 .376 .344 & 164.684 .840 & 289.037 .401 & 42.551 .449 & $14,72 \%$ \\
2007 & 89.102 & 5.281 .986 .014 & 1.031 .863 .212 & 253.869 .725 & 339.095 .947 & 50.058 .546 & $14,76 \%$ \\
2008 & 90.841 & 6.168 .513 .896 & 1.310 .370 .921 & 306.313 .650 & 424.004 .720 & 84.908 .773 & $20,02 \%$ \\
2009 & 91.106 & 8.050 .790 .537 & 1.637 .828 .174 & 352.777 .275 & 666.999 .512 & 242.994 .792 & $36,43 \%$ \\
2010 & 91.985 & 9.384 .937 .844 & 1.785 .243 .486 & 440.058 .218 & 955.844 .469 & 288.844 .957 & $30,21 \%$ \\
2011 & 93.229 & 11.082 .229 .330 & 1.995 .404 .153 & 535.707 .410 & 1.009 .309 .945 & 53.465 .476 & $5,29 \%$ \\
2012 & 94.875 & 12.650 .901 .298 & 2.351 .737 .261 & 569.442 .236 & 1.164 .549 .436 & 155.239 .491 & $13,33 \%$ \\
\hline Sumber : Laporan RAT PKP-RI tahun 2000-2012 (diolah) & & & & &
\end{tabular}

Berdasarkan tabel perkembangan Sisa Hasil Usaha di atas, dapat dilihat terjadi penurunan anggota yang secara terus menerus pada tahun 2001 sampai dengan tahun 2006 sedangkan pada tahun tersebut simpanan anggota meningkat terus menerus. Pada tahun 2002 ke tahun 2003 terjadi peningkatan simpanan anggota, akan tetapi pada tahun tersebut partisipasi anggota mengalami penurunan dan Sisa Hasil Usaha juga mengalami penurunan.
PKP-RI Propinsi Sumatera Barat selama ini telah melakukan beberapa usaha dalam rangka mendapatkan laba atau SHU yang maksimal.Sejak berdirinya koperasi ini para pengurus dan anggotanya telah berhasil menjalankan usaha perkoperasian dengan baik, dan juga koperasi ini mengalami kenaikan dan penurunan dalam memperoleh SHU. 


\section{Pengertian Koperasi}

Koperasi berasal dari kata Codan Operation yang mengandung arti bekerja sama untuk mencapai tujuan. Pengertian koperasi menurut Undang-Undang No.17 tahun 2012 tentang perkoperasian menyatakan bahwa, "badan hukum yang didirikan oleh orang perseorangan atau badan hukum koperasi, dengan pemisahan kekayaan para anggotanya sebagai modal untuk menjalankan usaha, yang memenuhi aspirasi dan kebutuhan bersama di bidang ekonomi, sosial, dan budaya sesuai dengan nilai dan prinsip koperasi".

Menurut Rudianto (2010:3), koperasi adalah suatu perkumpulan yang didirikan oleh orang-orang yang memiliki kemampuan ekonomi terbatas, yang bertujuan untuk memperjuangkan peningkatan kesejahteraan ekonomi mereka.

\section{Tujuan Koperasi}

Menurut Undang-Undang Republik Indonesia No. 17 tahun 2012 tetang perkoperasian bab II pasal 4 menyatakan bahwa, "Koperasi bertujuan untuk meningkatkan kesejahteraan anggota pada khususnya dan masyarakat pada umumnya, sekaligus sebagai bagian yang tidak terpisahkan dari tatanan perekonomian nasional yang demokratis dan berkeadilan".

Perihal fungsi dan peran koperasi, Undang-Undang Repulik Indonesia No.17 tahun 2012 menyatakan fungsi dan peran koperasi adalah:

a) Membangun dan mengembangkan potensi dan kemampuan ekonomi anggota pada khususnya dan masyarakat pada umumnya untuk meningkatkan kesejahteraan ekonomi dan sosialnya.

b) Berperan secara aktif dalam upaya mempertinggi kualitas kehidupan manusia dan masyarakat.

c) Memperkokoh perekonomian rakyat sebagai dasar kekuatan dan ketahanan perekonomian nasional dengan koperasi sbagai sokogurunya.

d) Berusaha untuk mewujudkan dan mengembangkan perekonomian nasional yang merupakan usaha bersama berdasarkan atas azas kekeluargaan dan demokrasi ekonomi.

\section{Jenis-Jenis Koperasi}

Jenis-jenis koperasi yang dibagi dalam 5 jenis sebagaimana yang dikemukakan Anoraga (1993:18)dalam buku "Dinamika Koperasi” yaitu :

1. Koperasi Konsumsi

Barang konsumsi adalah barang kebutuhan sehari-hari, misalnya barang pangan, barang sandang dan barang pembantu keperluan sehari-hari. Tujuan koperasi adalah agar para anggotanya dapat membeli barangbarang dengan mutu yang baik dan harga yang layak.

2. Koperasi Simpan Pinjam

Koperasi menerima simpanansimpanan dan deposito dari para anggotanya serta memberikan pinjaman bagi anggota yang sama.

3. Koperasi Produksi

Koperasi produksi sebagai suatu badan usaha yang dimiliki oleh para karyawan/pekerjanya (koperasi produsen).

4. Koperasi Jasa

Koperasi jasa diorganisir untuk dapat melayani para anggotanya dengan pelayanan yang lebih meningkat, seperti : asuransi, kredit, telepon, dan lain-lain.

5. Koperasi Serba Usaha

Koperasi serba usaha yaitu koperasi yang menyelenggarakan usaha lebih dari satu macam kebutuhan ekonomi atau kepentingan ekonomi para anggotanya.

\section{Keanggotaan Koperasi}

Sebagai suatu perkumpulan, koperasi tidak akan terbentuk tanpa anggota sebagai tulang punggungnya, semakin banyak anggota maka semakin kokoh kedudukan koperasi. Sebab badan usaha koperasi dikelola serta dibiayai oleh para anggota, hal ini terlihat dari pemasukan modal koperasi yang bersumber dari simpanan simpanan para anggota, yang dikelompokkan sebagai modal sendiri atau modal equity. Disamping itu menurut 
ketentuan Pasal 26 ayat ( 1 ) UU No. 17 Tahun 2012, dinyatakan bahwa anggota koperasi Indonesia adalah merupakan pemilik sekaligus sebagai pengguna jasa koperasi.

Di dalam ketentuan Pasal 26 ayat (3) UU No.17 Tahun 2012, dinyatakan bahwa keanggotaan koperasi bersifat terbuka bagi semua yang bisa dan mampu menggunakan jasa koperasi dan bersedia menerima tanggung jawab keanggotaan.

Dalam ketentuan Pasal 27 ayat (1) UU No.17 Tahun 2012 dinyatakan bahwa yang dapat menjadi anggota koperasi adalah setiap warga negara Indonesia yang mampu melakukan tindakan hukum, atau koperasi yang memenuhi persyaratan seperti ditetapkan dalam anggaran dasar.

Adapun kewajiban dari setiap anggota koperasi seperti tercantum di dalam ketentuan Pasal 29 ayat (1) UU No.17 tahun 2012, sebagai berikut :

1. Mematuhi Anggaran Dasar, Anggaran Rumah Tangga, dan keputusan Rapat Anggota.

2. Berpartisipasi aktif dalam kegiatan usaha yang diselenggarakan koperasi.

3. Mengembangkan dan memelihara nilai kekeluargaan, menolong diri sendiri, bertanggung jawab, demokrasi, persamaan, berkeadilan, dan kemandirian.

Sedangkan hak dari setiap anggota koperasi seperti tercantum di dalam pasal 29 ayat (2) UU No.17 Tahun 2012, sebagai berikut:

1) Menghadiri, menyatakan pendapat, dan memberikan suara dalam Rapat Anggota.

2) Mengemukakan pendapat atau saran kepada pengurus di luar Rapat Anggota baik diminta atau tidak.

3) Memilih atau dipilih menjadi pengawas atau pengurus.

4) Meminta diadakan rapat anggota menurut ketentuan dalam anggaran dasar.

5) Memanfaatkan jasa yang disediakan koperasi.

6) Mendapat keterangan mengenai perkembangan koperasi sesuai dengan ketentuan dalam anggaran dasar.

7) Mendapatkan selisih hasil usaha koperasi dan kekayaan sisa hasil penyelesaian koperasi.

Menurut Widiyanti (2003), keanggotaan koperasi berakhir bilamana anggota bersangkutan :

a. Meninggal dunia.

b. Meminta berhenti atas kehendak sendiri.

c. Diberhentikan oleh pengurus karena tidak memenuhi lagi syarat-syarat keanggotaan.

d. Dipecat oleh pengurus karena tidak mengindahkan kewajiban sebagai anggota.

\section{Modal Usaha Koperasi}

Menurut Kartasapoetra (2005:45), modal koperasi terdiri dari simpanansimpanan pokok, wajib, dan sukarela para anggota (dalam hal ini dapat pula diterima pula simpanan sukarela dari bukan anggota, pinjaman-pinjaman, dan penyisihan hasil usaha (termasuk cadangan-cadangan) dan sumber-sumber lain.

Menurut Sitio ( 2001:82 ), Modal yang ada dalam koperasi terdiri dari modal sendiri dan modal pinjaman.

\section{Modal Sendiri}

Modal sendiri dalam koperasi terdiri dari :

1. Simpanan pokok, adalah sejumlah uang yang sama banyaknya, yang wajib dibayarkan oleh masingmasing anggota kepada koperasi pada saat masuk menjadi anggota.

2. Simpanan wajib, adalah sejumlah simpanan tertentu yang tidak harus sama banyaknya, yang wajib dibayarkan oleh anggota kepada koperasi pada periode tertentu.

3. Dana cadangan, adalah sejumlah dana yang diperoleh dari penyisihan sisa hasil usaha dan dicadangkan untuk menutupi kerugian koperasi bila diperlukan.

4. Donasi, yaitu sejumlah uang atau barang dengan nilai tertentu yang disumbangkan oleh pihak ketiga, tanpa ada suatu ikatan atau 
kewajiban

untuk mengendalikannya.

\section{Modal Pinjaman}

Modal Pinjaman atau modal luar bersumber dari :

1. Anggota.

2. Koperasi lainnya.

3. Bank dan lembaga keuangan lainnya.

4. Lembaga keuangan non bank.

5. Penerbitan obligasi dan surat hutang lainnya.

6. Sumber lain yang sah.

Menurut Widiyanti (2003), Modal dalam perkumpulan koperasi didapat dari tiga unsur yaitu sebagai berikut :

a. Dari anggotanya sendiri, berupa simpanan-simpanan.

b. Dari sisa hasil usaha, yaitu bagian yang dimasukkan cadangan-cadangan.

c. Dan dari luar, misalnya pinjaman.

\section{Partisipasi Anggota}

Menurut Anoraga

(1993:111), partisipasi anggota merupakan kesediaan anggota itu untuk memikul kewajiban dan menjalankan hak keanggotaanya secara bertanggung jawab. Jika sebagian besar anggota koperasi sudah melaksanakan kewajiban dan melaksanakan hak secara bertanggung jawab.

Menurut Ropke (2000:45) partisipasi dibutuhkan untuk mengurangi kinerja yang minim, "deter malpractices" dan membuat para pemimpin koperasi diperhitungkan orang.Partisipasi anggota sering disebut sebagai alat pengembangan maupun sebagai tujuan akhir itu sendiri.

Menurut Anoraga (1993:112), berbagai indikasi yang muncul sebagai ciri-ciri anggota yang berpartisipasi baik dapat dirumuskan sebagai berikut;

1. Melunasi simpanan pokok dan simpanan wajib secara tertib dan teratur.

2. Membantu modal koperasi disamping simpanan pokok dan wajib sesuai dengan kemampuan masing-masing.

3. Menjadi pelanggan koperasi yang setia.

4. Menghadiri rapat-rapat dan pertemuan secara aktif.

5. Menggunakan hak untuk mengawasi jalannya usaha koperasi,
Partisipasi anggota tidak terlepas dari status anggota koperasi sebagai suatu badan usaha yaitu sebagai pemilik (owner) dan sebagai pemakai (user).Sebagai pemilik, kewajiban anggota adalah melakukan investasi atau menanamkan modal di koperasinya.Sedangkan sebagai pemakai, anggota harus menggunakan secara maksimal pelayanan usaha yang diselenggarakan oleh koperasi. Oleh sebab itu, status keanggotaan koperasi menjadi basis utama bagi perkembangan dan kelanjutan hidup usaha koperasi (Sitio, 2001;79).

\section{Penjualan}

Menurut Sadeli (2006:01), penjualan adalah aktivitas yang berinteraksi langsung dengan konsumen untuk memperoleh pesanan atau penjualan langsung, dan juga menyangkut masalah sifat/sikap penjual maupun pembeli.

Volume usaha adalah total nilai penjualan atau penerimaan dari barang dan jasa pada suatu periode atau tahun buku yang bersangkutan (Sitio, 2001:141). Dengan demikian volume usaha koperasi adalah akumulasi nilai penerimaan barang dan jasa sejak awal tahun buku sampai dengan akhir tahun buku.

Ilmu seni menjual adalah pengetahuan tentang suatu bidang yang disusun secara teratur, sedangkan menjual berarti suatu tindakan untuk menukar barang atau jasa dengan uang dengan cara mempengaruhi orang lain agar mau memiliki barang yang ditawarkan sehingga kedua belah pihak mendapatkan keuntungan dan kepuasan (Sadeli, 2006:04).

Berdasarkan penjelasan diatas, maka penjualan atau volume usaha adalah total nilai penjualan atau penerimaan dari barang dan atau jasa pada suatu periode waktu atau tahun buku yang bersangkutan. Penjualan berkaitan dengan skala ekonomi, semakin besar penjualan atau volume usaha suatu koperasi berarti semakin besar potensinya sebagai perusahaan, sehingga dapat memberikan pelayanan dan jasa yang lebih baik kepada para anggota

\section{Sisa Hasil Usaha (SHU)}

Menurut Pachta (2005:128), SHU adalah merupakan laba atau keuntungan 
yang diperoleh dari menjalankan usaha sebagaimana layaknya sebuah perusahaan bukan koperasi.

Menurut IAI (2004:275), Sisa Hasil Usaha adalah penjumlahan dari partisipasi neto dan laba atau rugi kotor dengan non anggota, ditambah atau dikurangi dengan pendapatan dan beban lain serta beban perkoperasian pajak penghasilan badan koperasi.

Menurut Rudianto (2010:7), SHU adalah selisih antara penghasilan yang diterima selama periode tertentu dan pengorbanan yang dikeluarkan untuk memperoleh penghasilan itu.

Menurut Undang-Undang No.17 Tahun 2012 tentang Perkoperasian Pasal 1 menyatakan bahwa: selisih hasil usaha adalah surplus hasil usaha atau defisit hasil usaha yang diperoleh dari hasil usaha atau pendapatan koperasi dalam satu tahun buku setelah dikurangi dengan pengeluaran atas berbagai beban usaha.

Menurut Sitio (2001:89), acuan dasar untuk membagi SHU adalah prinsipprinsip dasar koperasi yang menyebutkan bahwa pembagian SHU dilakukan secara adil sebanding dengan besarnya jasa usaha masing-masing anggota.

\section{Faktor-Faktor Yang Mempengaruhi Sisa Hasil Usaha}

Menurut Pachta (2005:56), faktorfaktor yang mempengaruhi SHU terdiri dari 2 faktor yaitu :

1. Faktor dari Dalam

a. Partisipasi anggota, para anggota koperasi harus berpartisipasi dalam kegiatan koperasi karena tanpa adanya peran anggota maka koperasi tidak akan berjalan lancar.

b. Jumlah modal sendiri, SHU anggota yang di peroleh sebagian dari modal sendiri yaitu dari simpanan wajib, simpanan pokok, dana cadangan dan hibah.

c. Kinerja pengurus, kinerja pengurus sangat di perlukan dalam semua kegiatan yang dilakukan oleh koperasi, dengan adanya kinerja yang baik dan sesuai persyaratan dalam Anggaran Dasar serta UU
Perkoperasian maka hasil yang di capaipun juga akan baik.

d. Jumlah unit usaha yang dimiliki, Setiap koperasi pasti memiliki unit usaha hal ini juga menentukan seberapa besar volume usaha yang di jalankan dalam kegiatan usaha tersebut.

e. Kinerja manajer, kinerja manajer menentukan jalannya semua kegiatan yang dilakukan oleh koperasi dan memiliki wewenang atas semua hal-hal yang bersifat intern.

f. Kinerja karyawan, merupakan kemampuan seorang karyawan dalam menjadi anggota koperasi.

2. Faktor dari Luar

1. Modal pinjaman dari luar.

2. Para konsumen dari luar selain anggota koperasi.

3. Pemerintah.

Berdasarkan penelitian Iramani dan Kristijadi (1997), faktor-faktor yang mempengaruhi SHU :

a. Jumlah anggota koperasi.

b. Volume usaha.

c. Jumlah simpanan.

d. Jumlah hutang.

\section{METODE PENELITIAN}

Jenis penelitian yang digunakan dalam penelitian ini adalah penelitian kuantitatif. Sarwono (2006) mendefinisikan bahwa :metode penelitian kuantitatif adalah penelitian ilmiah yang sistematis terhadap bagian-bagian dan fenomena serta hubungan-hubungannya.

Penelitian ini dilakukan di PKP-RI (Pusat Koperasi Pegawai Republik Indonesia) Propinsi Sumatera Barat.Penelitian untuk penulisan ini berlangsung pada 31 Mei 2013 s.d 31 Agustus 2013.

Dalam penelitian ini ada dua variabel yang digunakan yaitu :

1. Variabel independen/bebas yaitu jumlah anggota (X1), simpanan anggota (X2), partisipasi anggota (X3) dan penjualan $(\mathrm{X} 4)$

2. Variabel dependen/terikat yaitu sisa hasil usaha (Y) 
Sumber Data Penelitian

1. Data Primer, Menurut Sarwono (2006:123), data primer adalah data yang hanya dapat kita peroleh dari sumber asli atau pertama.

2. Data Sekunder, Menurut Sarwono (2006:123), data sekunder adalah data yang sudah tersedia sehingga kita tinggal mencari dan mengumpulkan.

Data yang akan dipakai dalam penelitian ini berupa data sekunder. Data sekunder yang akan digunakan yaitu data deret waktu tahunan (time series) dari tahun 2000 - 2012 berupa jumlah anggota, simpanan anggota, partisipasi anggota, penjualan, dan sisa hasil usaha PKP-RI Propinsi Sumatera Barat.

\section{PEMBAHASAN}

\section{Faktor-Faktor Yang Mempengaruhi SHU}

Berdasarkan hasil olahan data, diperoleh persamaan regresi linear berganda :

$\mathrm{Y}=-113,07+10,667 X_{1}+0,546 X_{2}-$ $0,047 X_{4}+\mathrm{e}_{\mathrm{i}}$

Interpretasi dari regresi tersebut adalah sebagai berikut:

1. Intersep $\left(\beta_{0}\right)$

Ini berarti jika semua variabel bebas memiliki nilai nol (0) maka nilai variabelterikat sebesar -113,07.

2. Jumlah Anggota $\left(X_{1}\right)$ terhadap SHU (Y)

Nilai koefisien jumlah anggota untuk variabel $\mathrm{X}_{1}$ sebesar 10,667. Hal ini mengandung arti bahwa setiap kenaikan jumlah anggota $1 \%$ maka variabel SHU (Y) akan naik sebesar $10,667 \%$ dengan asumsi bahwa variabel bebas yang lain dari model regresi adalah tetap.

3. Simpanan Anggota $\left(\mathrm{X}_{2}\right)$ terhadap SHU (Y)

Nilai koefisien simpanan anggota untuk variabel $\mathrm{X}_{2}$ sebesar 0,546. Hal ini mengandung arti bahwa setiap kenaikan simpanan anggota $1 \%$ maka variabel SHU (Y) akan naik sebesar $0,546 \%$ dengan asumsi bahwa variabel bebas yang lain dari model regresi adalah tetap.

4. Penjualan $\left(\mathrm{X}_{4}\right)$ terhadap SHU (Y)
Nilai koefisien penjualan untuk variabel $\mathrm{X}_{4}$ sebesar -0,047. Hal ini mengandung arti bahwa setiap kenaikan penjualan $1 \%$ maka variabel SHU (Y) akan turun sebesar 0,047\% dengan asumsi bahwa variabel bebas yang lain dari model regresi adalah tetap.

\section{Kemampuan Variabel Independen Dalam Menjelaskan Variasi VariabelDependen}

Berdasarkan hasil olahan data diperoleh nilai koefisien determinasi adalah sebesar 0,8817 artinya $88,17 \%$ dari sisa hasil usaha koperasi PKP-RI dipengaruhi oleh jumlah anggota, simpanan anggota, dan penjualan sedangkan sisanya $11,83 \%$ dipengaruhi oleh variabel lain yang tidak digunakan dalam model penelitian ini.

\section{Uji Signifikansi Variabel Independen Secara Parsial Terhadap VariabelDependen}

Berdasarkan hasil olahan data, dimana diperoleh $t_{\text {hitung }}$ simpanan anggota sebesar 4,548 lebih besar dari $t_{\text {tabel }}$ sebesar 2,262.Dengan demikian $\mathrm{H}_{0}$ ditolak dan $\mathrm{H}_{1}$ diterima, artinya variabel simpanan anggota berpengaruh signifikan terhadap peningkatan SHU PKP-RI.Terdapat juga pengaruh yang signifikan antara jumlah anggota terhadap peningkatan sisa hasil usaha PKP-RI Propinsi Sumatera Barat.Dimana diperoleh $t_{\text {hitung }}$ sebesar 3,575 lebih besar dari $t_{\text {tabel }}$ sebesar 2,262.Dengan demikian $\mathrm{H}_{0}$ ditolak dan $\mathrm{H}_{1}$ diterima, artinya variabel jumlah anggota berpengaruh signifikan terhadap peningkatan SHU PKP-RI Sedangkan tidak terdapat pengaruh yang signifikan antara penjualan terhadap peningkatan sisa hasil usaha PKP-RI Propinsi Sumatera Barat.Dimana diperoleh $t_{\text {hitung }}$ sebesar 0,165 lebih kecil dari $t_{\text {tabel }}$ sebesar 2,262.

Uji Signifikansi Variabel Independen Secara Bersama-Sama Terhadap Variabel

Berdasarkan hasil olahan data, dimana diperoleh $F_{\text {hitung }} 22,37$ dan diperoleh $F_{\text {tabel }}$ dengan tingkat kesalahan 5\% sebesar 3,86, maka diperoleh $F_{\text {hitung }} 22,37$ lebih besar dari $F_{\text {tabel }}$ 3,86. Dapat disimpulkan bahwa 
$\mathrm{H}_{0}$ ditolak dan $\mathrm{H}_{1}$ diterima, dengan artian jumlah anggota, simpanan anggota, dan penjualan berpengaruh terhadap peningkatan SHU PKP-RI Propinsi Sumatera Barat.

\section{PENUTUP}

\section{Kesimpulan}

Berdasarkan pertanyaan penelitian dan pembahasan hasil yang telah dilakukan, maka dikemukakan kesimpulan sebagai berikut :

1. Berdasarkan hasil olahan data dengan analisis regresi berganda dan pembahasan terhadap hasil, nilai koefisien jumlah anggota sebesar 10,667 yang berarti setiap kenaikan jumlah anggota $1 \%$ maka SHU akan naik sebesar $10,667 \%$. Nilai koefisien simpanan anggota sebesar 0,546 yang berarti setiap kenaikan simpanan anggota 1\% maka SHU akan naik sebesar 0,546\%. Nilai koefisien penjualan sebesar -0,047 yang berarti setiap kenaikan penjualan $1 \%$ maka SHU akan turun sebesar $-0,047 \%$. Dengan demikian faktor-faktor yang mempengaruhi sisa hasil usaha pada PKP-RI Propinsi Sumatera Barat yaitu jumlah anggota dan simpanan anggota.

2. Secara bersama-sama jumlah anggota (X1), simpanan anggota (X2), dan penjualan (X4) berpengaruh secara signifikan terhadap peningkatan sisa hasil usaha (Y), artinya secara bersama-sama peningkatan SHU ditentukan oleh variabel bebas dalam penelitian ini. Dimana diperoleh $\mathrm{F}_{\text {hitung }}$ 22,37 dan diperoleh $F_{\text {tabel }}$ dengan tingkat kesalahan 5\% sebesar 3,86, maka diperoleh $\mathrm{F}_{\text {hitung }} 22,37$ lebih besar dari $\mathrm{F}_{\text {tabel }}$ 3,86. Dapat disimpulkan bahwa $\mathrm{H}_{0}$ ditolak dan $\mathrm{H}_{1}$ diterima, dengan artian jumlah anggota, simpanan anggota, dan penjualan berpengaruh terhadap peningkatan SHU PKP-RI Propinsi Sumatera Barat.

3. Terjadi pengaruh yang signifikan antara simpanan anggota terhadap peningkatan sisa hasil usaha PKP-RI Propinsi Sumatera Barat. Dimana diperoleh $\mathrm{t}_{\text {hitung }}$ sebesar 4,548 lebih besar dari $t_{\text {tabel }}$ sebesar 2,262. Dengan demikian $\mathrm{H}_{0}$ ditolak dan $\mathrm{H}_{1}$ diterima, artinya variabel simpanan anggota berpengaruh signifikan terhadap peningkatan SHU PKP-RI. Terdapat juga pengaruh yang signifikan antara jumlah anggota terhadap peningkatan sisa hasil usaha PKP-RI Propinsi Sumatera Barat. Dimana diperoleh $t_{\text {hitung }}$ sebesar 3,575 lebih besar dari $t_{\text {tabel }}$ sebesar 2,262. Dengan demikian $\mathrm{H}_{0}$ ditolak dan $\mathrm{H}_{1}$ diterima, artinya variabel jumlah anggota berpengaruh signifikan terhadap peningkatan SHU PKP-RI Sedangkan tidak terdapat pengaruh yang signifikan antara penjualan terhadap peningkatan sisa hasil usaha PKP-RI Propinsi Sumatera Barat. Dimana diperoleh $t_{\text {hitung }}$ sebesar 0,165 lebih kecil dari $t_{\text {tabel }}$ sebesar 2,262. Dengan demikian $\mathrm{H}_{1}$ ditolak dan $\mathrm{H}_{0}$ diterima, artinya variabel penjualan tidak berpengaruh secara signifikan terhadap peningkatan SHU PKP-RI. Jadi yang mempunyai pengaruh signifikan terhadap peningkatan SHU PKP-RI Propinsi Sumatera Barat adalah simpanan anggota, karena diperoleh $t_{\text {hitung }}$ sebesar 4,548 .

\section{Saran}

Berdasarkan kesimpulan, maka penulis menyarankan beberapa hal sebagai berikut :

1. Sehubungan hasil penelitian yang ditemukan bahwa faktor-faktor yang mempengaruhi sisa hasil usaha PKP-RI Propinsi Sumatera Barat adalah jumlah anggota dan simpanan anggota. Oleh karena itu penulis menyarankan kepada pengurus koperasi agar dapat meningkatkan pelayanan koperasi sehingga dapat menambah jumlah anggota, dengan bertambahnya jumlah anggota maka simpanan anggota juga akan bertambah sehingga sisa hasil usaha pada koperasi dapat meningkat.

2. Sehubungan hasil penelitian yang menyatakan bahwa secara bersamasama jumlah anggota, simpanan anggota, dan penjualan berpengaruh 
terhadap peningkatan sisa hasil usaha koperasi, maka disarankan kepada pengurus agar meningkatkan pelayanan koperasi agar jumlah anggota koperasi bertambah dan kepada anggota untuk tetap melaksanakan hak dan kewajibannya terhadap koperasi yaitu dengan melakukan simpanan, serta bagi pengurus dan anggota agar meningkatkan pelayanan dalam hal penjualan agar sisa hasil usaha pada koperasi dapat meningkat.

3. Sehubungan hasil penelitian yang ditemukannya simpanan anggota berpengaruh signifikan daripada jumlah anggota dan penjualan, maka diharapkan kepada anggota untuk tetap melakukan hak dan kewajibannya dengan melakukan simpanan, karena dengan simpanan dapat menentukan perkembangan sebuah koperasi.

\section{DAFTAR PUSTAKA}

10.22202/economica.2014.v2.i2.224

Agustin S.R dan Beny S. 2011.Pengaruh Modal Sendiri, Modal Luar, dan Volume Usaha Pada Sisa Hasil Usaha Koperasi di Provinsi Daerah istimewa Yogyakarta. Review jurnal ekonomi koperasi 4 bag. 1.

Anoraga, Panji dan Ninik Widiyanti. 1993. Dinamika Koperasi. Jakarta : Rineka Cipta.

Arikunto, Suharsimi. 2009. Manajemen Penelitian. Jakarta : PT. Rineka Cipta.

G. Kartasapoetra. 2005. Praktek Pengelolaan Koperasi. Jakarta : PT. Rineka Cipta.

Hasnawati. 2004. Pengaruh Partisipasi Anggota Terhadap Sisa Hasil Usaha Pada Koperasi Samudera Sejahtera Samarinda Tahun Buku 1999-2003. Review jurnal ekonomi koperasi 4 bag. 1.

Ikatan Akuntan Indonesia. PSAK No. 27. 2002. Akuntan Perkoperasian. Jakarta: Erlangga.

Iramani dan E. kristijadi. 1997. FaktorFaktor Yang Mempengaruhi Sisa Hasil
Usaha Koperasi Unit Desa di Jawa Timur. Jurnal Ventura : Vol. 1, No. 2, hal 73-79.

Ismail, Agus Taufik. 2007. Pengaruh Partisipasi Anggota Koperasi Terhadap Sisa Hasil Usaha di Koperasi Pegawai Negeri (KP-RI) Tumbal Kecamatan Ciamis, Kabupaten Ciamis.Skripsi.

Laporan RAT Tahun Buku 20002012.Pusat Koperasi Pegawai Republik Indonesia (PKP-RI) Propinsi Sumatera Barat.

Liana, April. 2009. Faktor-Faktor Yang Mempengaruhi Sisa Hasil Usaha Pada Koperasi Waru Buana Putra di Sidoarjo. Skripsi.

Pachta W, Andjar dkk. 2005. Manajemen Koperasi : Teori dan Praktik. http://elib.unikom.ac.id/files/disk1/599/ jbptunikompp-gdl-wulanismay-299407-unikomw-i.pdf diakses 15 April 2013.

Ribut Setyawan, Andri. 2011. Pengaruh Modal Sendiri dan Jumlah Anggota Terhadap Perolehan Sisa Hasil Usaha Koperasi Serba Usaha (KSU) di Kabupaten Sidoarjo. Skripsi.

Ropke, Jochen. 2000. Ekonomi Koperasi Teori dan Manajemen.Jakarta : Salemba Empat.

Rudianto. 2010. Akuntansi Koperasi. Jakarta : Erlangga.

Sadeli, Ukas Maman. 2006. Pengantar Bisnis ilmu Menjual.Jakarta : PT. Bumi Aksara.

Sarwono, Jonathan. 2006. Metode Penelitian Kuantitatif \& Kualitatif.Yogyakarta : Graha Ilmu.

Sitio, Arifin ; Tamba, Halomoan. 2001. Koperasi Teori dan Praktik.Jakarta : Erlangga.

Undang-Undang Republik Indonesia Nomor 17 Tahun 2012.

Widarjono, Agus. 2009. Ekonometriika Pengantar dan Aplikasinya.Yogyakarta : Ekonisia.

Widiyanti, Ninik dan Y.W Sunindhia. 2003. Koperasi dan Perekonomian Indonesia. Jakarta : Rineka Cipta. 